\title{
Nutrition of Tithonia diversifolia and attributes of the soil fertilized with biofertilizer in irrigated system
}

\author{
Matheus M. Reis ${ }^{1}$, Leonardo D. T. Santos ${ }^{2}$, Rodinei F. Pegoraro ${ }^{2}$, \\ Fernando Colen ${ }^{2}$, Leonardo M. Rocha ${ }^{2}$ \& Guilherme A. de P. Ferreira ${ }^{2}$ \\ ${ }^{1}$ Universidade Estadual de Campinas/Faculdade de Engenharia Agrícola. Campinas, SP. E-mail: matheussmendes@hotmail.com (Corresponding author) \\ ${ }^{2}$ Universidade Federal de Minas Gerais/Instituto de Ciências Agrárias. Montes Claros, MG. E-mail: Ituffi@yahoo.com.br; rodinei_pegoraro@yahoo.com.br; \\ fernandocolen1@yahoo.com.br; leonardorocha.agronomia@gmail.com; guilhermepaiva017@gmail.com
}

\section{Key words:}

organic fertilizer

Tithonia

nutrient content

rainfed crop

forage

\begin{abstract}
A B S T R A C T
The fertilization with biofertilizer associated with the use of irrigation favors nutrient uptake by plants and soil chemical properties; however, these effects are little studied in Tithonia diversifolia in semiarid regions. This study evaluated the effect of doses of bovine biofertilizer and irrigation on accumulation of nutrients in the leaves of Tithonia diversifolia plants and on soil chemical attributes. The study was carried out from December 3, 2014 to November 28, 2015, and arranged in a $2 \times 5$ factorial scheme, consisting of five doses of bovine biofertilizer $\left(0,40,80,120\right.$ and $\left.160 \mathrm{~m}^{3} \mathrm{ha}^{-1}\right)$, combined with and without irrigation. The experiment was set in a randomized block design, using three replicates. Irrigation promoted increased accumulation of $\mathrm{N}, \mathrm{P}, \mathrm{K}, \mathrm{Ca}, \mathrm{Mg}, \mathrm{S}, \mathrm{Zn}, \mathrm{Fe}, \mathrm{Mn}, \mathrm{Cu}$ and $\mathrm{B}$ in leaves of Tithonia diversifolia in the first cutting. However, the high bicarbonate concentration in the irrigation water and the occurrence of rainfall during the second crop increased the accumulation of $\mathrm{Cu}$ in the leaves of Tithonia diversifolia under rainfed condition, compared with irrigated plants. The increase in biofertilizer doses contributed to the increment of base saturation and the contents of organic matter, $\mathrm{P}$ and $\mathrm{K}$ in soil.
\end{abstract}

\section{Palavras-chave:}

adubação orgânica

Titônia

conteúdo de nutrientes

cultivo de sequeiro

forragem

\section{Nutrição de Tithonia diversifolia e atributos do solo adubado com biofertilizante em sistema irrigado}

\begin{abstract}
R E S U M O
Associada ao uso de irrigação, a adubação com biofertilizante favorece a absorção de nutrientes pelas plantas e as propriedades químicas dos solos, porém tais efeitos são pouco estudados no cultivo de Tithonia diversifolia em regiões semiáridas. Avaliaram-se os efeitos de doses de biofertilizante bovino e da irrigação no acúmulo foliar de nutrientes em plantas de Tithonia diversifolia e nos atributos químicos do solo. O estudo foi conduzido entre 3 de dezembro de 2014 e 28 de novembro de 2015 e distribuído em esquema fatorial $5 \times 2$, consistindo de cinco doses de biofertilizante bovino $\left(0,40,80,120\right.$ e $\left.160 \mathrm{~m}^{3} \mathrm{ha}^{-1}\right)$, combinado com e sem irrigação. O delineamento estatístico do experimento foi em blocos casualizados com três repetições. A irrigação promoveu aumento no acúmulo de $\mathrm{N}, \mathrm{P}, \mathrm{K}, \mathrm{Ca}, \mathrm{Mg}, \mathrm{S}$, $\mathrm{Zn}, \mathrm{Fe}, \mathrm{Mn}, \mathrm{Cu}$ e B em folhas de Tithonia diversifolia no primeiro corte; entretanto, a alta concentração de bicarbonato na água de irrigação e a presença de chuvas durante o segundo cultivo aumentaram o acúmulo de $\mathrm{Cu}$ nas folhas de Tithonia diversifolia em sequeiro quando comparado às plantas irrigadas. $\mathrm{O}$ aumento das doses de biofertilizante contribuiu para o incremento da saturação por base e do teor de matéria orgânica, P e K no solo.
\end{abstract}




\section{INTRODUCTION}

Tithonia diversifolia, popularly known as Mexican sunflower, is regarded as a promising source of feed for animals, because it is a perennial fast growing plant and has high capacity of recovery after cutting, even if it is close to the soil, besides achieving yields between 30 and $70 \mathrm{tha}^{-1}$ of green forage of high nutritional value. This forage is a bush from the Asteraceae family, originated from Central America and widely distributed in the tropical regions (Ruíz et al., 2014).

Besides its use as animal feed, $T$. diversifolia can be used as green fertilizer, vegetal cover of the soil, raw material in pharmaceutical industry, hedge and windbreak (Reis et al., 2015). In Brazil, it is frequently found on roadsides, pastures and vacant lots; however, there are no reports in the literature on the water requirements and soil fertility for this species.

The use of biofertilizers can be an interesting alternative for the reuse of organic waste, since they have high energetic content and expressive amounts of macro and micronutrients (Chiconato et al., 2013). The organic matter supplied through organic fertilizers improves soil chemical and physical characteristics and reduces costs with chemical fertilizers, besides allowing better use and storage of water in the soil (Krob et al., 2011; Sampaio et al., 2012).

As important as the reuse of wastes and reduction in the costs of fertilization is to know the relationship of the irrigation water in the processes of supply of nutrients in the soil and absorption of these nutrients by the plants (Roosta, 2011). This information indicates that the fertilization with biofertilizer and the use of irrigation alter the absorption of nutrients and the chemical attributes of soils cultivated with T. diversifolia. In this context, this study evaluated the effect of the use of bovine biofertilizer with and without irrigation on soil chemical attributes and on the accumulation of nutrients in the leaves of $T$. diversifolia.

\section{Material ANd Methods}

The experiment was carried out from December 3, 2014, to November 28, 2015, in Montes Claros, MG, Brazil ( $16^{\circ} 40^{\prime}$ $57.70^{\prime \prime} \mathrm{S} ; 43^{\circ} 50^{\prime} 19.62^{\prime \prime} \mathrm{W} ; 650 \mathrm{~m}$ ). The climate of the region is characterized as Aw, according to Köppen's classification; the soil was classified as eutrophic Haplic Cambisol with loam clayey texture and its physico-chemical characteristics are described in Table 1.

The statistical design was in randomized blocks with three replicates, in a $5 \times 2$ factorial scheme, composed of five doses of bovine biofertilizer $\left(0,40,80,120\right.$ and $\left.160 \mathrm{~m}^{3} \mathrm{ha}^{-1}\right)$ and two irrigation managements (with and without water application through irrigation). These doses of biofertilizer corresponded to $0,50,100,150$ and $200 \%$ of the recommendation of $\mathrm{N}$ for sunflower (Ribeiro et al., 1999). Since there are no recommendations of fertilization for $T$. diversifolia, the recommendation for sunflower was used as a reference, due to the botanic and morphological proximity between these species.

The biofertilizer was chemically characterized (Table 1), according to the methodology proposed by MAPA (2007). Half of the doses of biofertilizers were applied three days before planting (December 3, 2014) and the other half as top-dressing immediately after the last standardizing cut (June 21, 2015). After top-dressing fertilization, two consecutive crops of $T$. diversifolia were conducted.

At planting, parts of the stem were distributed in an end-toend scheme in the planting furrows, at the depth of $0.10 \mathrm{~m}$, and later cut at each $0.40 \mathrm{~m}$. The experimental plots were composed of four furrows at spacing of $1.0 \mathrm{~m}$ between rows and $3 \mathrm{~m}$ of length, totaling $12 \mathrm{~m}^{2}$ of total area per plot; the observation area of $4 \mathrm{~m}^{2}$ was delimited in the center of each plot.

Irrigation was performed using a surface drip system with lateral lines (LDPE DN16) along each planting row. Drippers with flow rate of $4.0 \mathrm{~L} \mathrm{~h}^{-1}$ and pressure of $100 \mathrm{kPa}$ were installed every $0.60 \mathrm{~m}$ in the plots with water replenishment. In addition, a pressure-regulating valve (PRLG-15) and a manometer were installed in the beginning of the experimental area for greater efficiency of the system.

Irrigation was conducted based on reference evapotranspiration (ETo), daily calculated through the Penman-Monteith method (Allen et al., 2006) and the meteorological data were obtained from an automatic station (Model - Davis Vantage) (Figure 1).

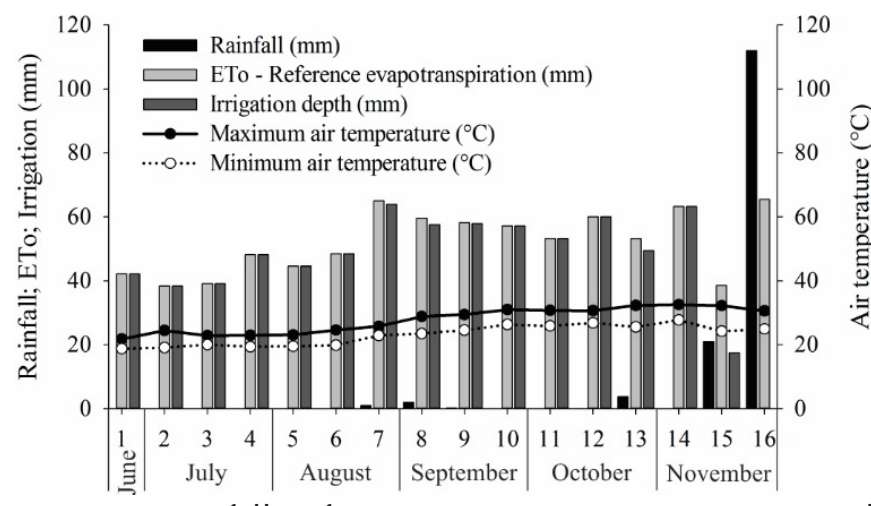

Figure 1. Rainfall, reference evapotranspiration (ETo) and irrigation depth accumulated every 10 days and maximum and minimum temperature along the experiment

Table 1. Physico-chemical characteristics of the soil in the experimental area in the layer of $0-0.20 \mathrm{~m}$ and chemical characteristics of the bovine biofertilizer applied at planting and as top-dressing in Tithonia diversifolia

\begin{tabular}{|c|c|c|c|c|c|c|c|c|c|c|c|c|}
\hline \multicolumn{13}{|c|}{ Soil } \\
\hline \multirow{3}{*}{$\begin{array}{c}\mathrm{pH} \\
\text { in } \mathrm{H}_{2} \mathrm{O}\end{array}$} & \multirow{2}{*}{$\begin{array}{c}\text { OM } \\
\mathrm{g} \mathrm{kg}^{-1}\end{array}$} & $\mathbf{P}$ & K & $\mathrm{Ca}$ & $\mathrm{Mg}$ & $\mathrm{Al}$ & $\mathrm{H}+\mathrm{Al}$ & CEC & V & Sand & Silt & Clay \\
\hline & & \multicolumn{2}{|c|}{$\mathrm{mg} \mathrm{dm}^{-3}$} & \multicolumn{5}{|c|}{$\mathrm{cmol}_{\mathrm{c}} \mathrm{dm}^{-3}$} & \multicolumn{4}{|c|}{$\%$} \\
\hline & 36.60 & 1.88 & 137.67 & 7.07 & 1.60 & 0.00 & 1.05 & 10.06 & 89.67 & 19.47 & 38.80 & 41.73 \\
\hline \multicolumn{13}{|c|}{ Bovine biofertilizer } \\
\hline \multirow{2}{*}{$\begin{array}{c}\mathrm{pH} \\
\text { in } \mathrm{CaCl}_{2}\end{array}$} & \multirow{2}{*}{$\begin{array}{c}E C \\
d S m^{-1}\end{array}$} & OM & $\mathrm{OC}$ & $\mathbf{N}$ & $\mathrm{P}_{2} \mathrm{O}_{5}$ & $\mathrm{~K}_{2} \mathrm{O}$ & $\mathrm{CaO}$ & $\mathrm{Mn}$ & $\mathrm{Fe}$ & $\mathrm{Mg}$ & $S$ & $\mathrm{Na}$ \\
\hline & & \multicolumn{11}{|c|}{$g^{-1}$} \\
\hline 7.66 & 5.27 & 16.51 & 9.14 & 1.56 & 1.30 & 1.76 & 0.56 & 0.76 & 0.32 & 0.69 & 0.22 & 0.26 \\
\hline
\end{tabular}

pH in distilled water. P and K, Mehlich-1 extractor. OM - Organic matter; V - Base saturation; EC - Electrical conductivity; OC - Organic carbon 
Inside the observation area of each plot, two disturbed single samples per composite sample of soil were collected in the layer of 0-0.2 m, 30 days after top-dressing fertilization (DAF) and at the first (80 DAF) and second (160 DAF) harvests of T. diversifolia. Organic matter, $\mathrm{pH}$ in water, $\mathrm{H}+\mathrm{Al}, \mathrm{P}, \mathrm{K}, \mathrm{Ca}$, $\mathrm{Mg}$ and $\mathrm{V}$ were evaluated in the soil (Silva, 2009).

The leaf contents of macro and micronutrients were determined through the collection, at 80 and $160 \mathrm{DAF}$, of the fourth fully expanded leaf from the apex to the base of the branches of 10 plants randomly selected inside the observation area of each plot. The material was taken to the laboratory, dried in a forced-air oven at $65^{\circ} \mathrm{C}$ until constant weight, ground in a Wiley-type mill and sieved (2-mm mesh) for later extraction through nitric/perchloric digestion $(\mathrm{P}, \mathrm{K}, \mathrm{Ca}, \mathrm{Mg}, \mathrm{S}, \mathrm{Cu}, \mathrm{Fe}$, $\mathrm{Mn}$ and $\mathrm{Zn}$ ), sulfuric digestion $(\mathrm{N})$ and calcination in a muffle furnace (B), as described by Silva (2009). The N content was determined through Semi-Micro Kjeldahl method and the other nutrients through atomic absorption spectrophotometry (Silva, 2009).

Plants were harvested 80 days after the beginning of each cultivation with one cut at $0.40 \mathrm{~m}$ from the soil, according to Ruíz et al. (2014). Leaf dry matter production was determined by weighing all the plants in the observation area of each plot and then the leaves and stems of five branches representative of the plot were taken to a forced-air oven at $65{ }^{\circ} \mathrm{C}$ until constant weight; the accumulation of nutrients in the leaves was determined based on the data of dry matter and contents of nutrients in the leaves.

Quantitative data were subjected to analysis of variance by $F$ test at 0.05 probability level and, in cases of significance, regression analysis was applied for the biofertilizer doses using the statistical program R-plus 3.2.1.

\section{Results AND Discussion}

The increase in biofertilizer doses in the non-irrigated cultivation of $T$. diversifolia promoted decrease in soil $\mathrm{pH}$ at $30 \mathrm{DAF}$ (Figure 2A), which may be attributed to the release of $\mathrm{H}^{+}$by the increment in microbial activity and to the formation of organic acids during the degradation of the organic matter in the soil (Villanueva et al., 2012). The addition of organic fertilizers in the soil promotes, initially, an increase in microbial activity (Figueiredo et al., 2012) and in the concentration of carbonic acid $\left(\mathrm{CO}_{2}+\mathrm{H}_{2} \mathrm{O} \leftrightarrow \mathrm{H}_{2} \mathrm{CO}_{3}\right)$ with its subsequent dissociation $\left(\mathrm{H}_{2} \mathrm{CO}_{3} \leftrightarrow \mathrm{HCO}_{3}+\mathrm{H}^{+}\right)$, which releases $\mathrm{H}^{+}$ions in the soil. These results corroborate those of Villanueva et al. (2012), who observed, in the same period (30 days), reduction in soil $\mathrm{pH}$ with the increase in the applied dose of sewage sludge.

The biofertilizer doses did not alter soil $\mathrm{pH}$ in the irrigated plots at $30 \mathrm{DAF}$, which remained at 7.65 (Figure 2A). The bicarbonate present in the irrigation water $\left(452.80 \mathrm{mg} \mathrm{L}^{-1}\right)$ may have contributed to the maintenance of a constant soil $\mathrm{pH}$, since the $\mathrm{HCO}_{3}$ contributed to the alkalization of the medium (Roosta, 2011).

Soil $\mathrm{pH}$ increased with the increment in the biofertilizer doses at 80 and 160 DAF (Figure 2B; Table 2). The degradation of the organic matter present in this fertilizer probably resulted in the release of organic compounds of simple molecular chain, such as low-molecular-weight organic acids, which favors the increase in $\mathrm{pH}$ due to the reaction of ligand exchange between organic anions and the terminal $\mathrm{OH}^{-}$in $\mathrm{Fe}$ and $\mathrm{Al}$ oxides (Pavinato \& Rosolem, 2008). The presence of $\mathrm{CaO}$ in the biofertilizer, due to its alkalizing effect, can also contribute to the increase of soil pH (Silva et al., 2014).

The application of $160 \mathrm{~m}^{3} \mathrm{ha}^{-1}$ of biofertilizer increased soil pH by 0.74 units compared with the non-fertilized plots, at 80 DAF (Table 2); at 160 DAF, there was also increase of soil $\mathrm{pH}$ with the doses of biofertilizer (Figure 2B) and the biofertilizer dose of $130.00 \mathrm{~m}^{3} \mathrm{ha}^{-1}$ promoted maximum values of $\mathrm{pH}$, equal to 7.84 and 7.74 for the soil with and without irrigation, respectively. These results corroborate those of Alves et al. (2009), who observed increase in soil $\mathrm{pH}$ with the addition of biofertilizer.

Irrigation also promoted increment in $\mathrm{pH}$ and reduction in potential acidity $(\mathrm{H}+\mathrm{Al})$ in all soil sampling periods (Figure 2; Table 2; Table 3), which can be justified by the fact that the water used in the experiment has low electrical conductivity $\left(0.36 \mathrm{dS} \mathrm{m}^{-1}\right)$ and high content of $\mathrm{HCO}_{3}\left(452.80 \mathrm{mg} \mathrm{L}^{-1}\right)$, which may lead to increase in soil pH (Roosta, 2011). Shahabi et al. (2005) observed increase of $\mathrm{pH}$ due to the addition of bicarbonate to the soil through the irrigation water.
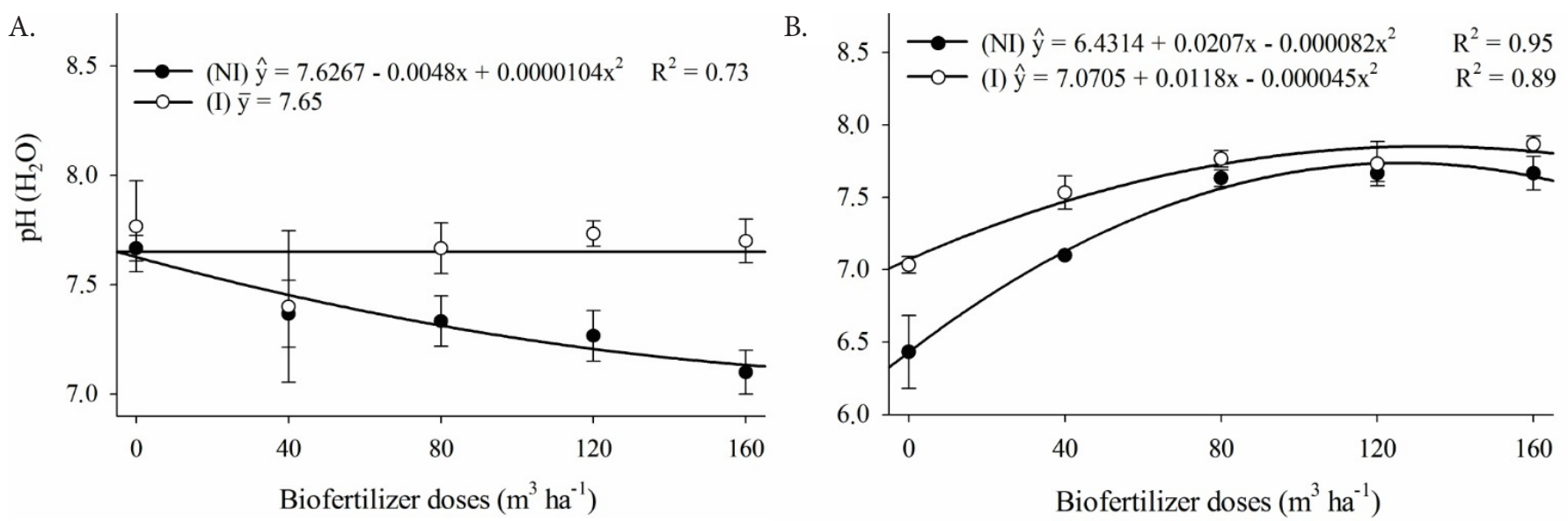

Figure 2. Values of $\mathrm{pH}$ of soil samples collected in the layer of $0-20 \mathrm{~cm}$ cultivated with Tithonia diversifolia fertilized with bovine biofertilizer under irrigated (I) and non-irrigated (NI) conditions at 30 (A) and 160 (B) days after the beginning of the experiment 
Table 2. Regression equations relative to soil chemical attributes as a function of the application of bovine biofertilizer

\begin{tabular}{|c|c|c|c|c|c|c|}
\hline Variables & Unit & $\begin{array}{c}\text { Equation } \\
\end{array}$ & $\mathbf{R}^{2}$ & BFB $\left(m^{3} h a^{-1}\right)$ & MxMn & CF \\
\hline pH (80 DAF) & in $\mathrm{H}_{2} \mathrm{O}$ & $\widehat{Y}=6.9175+0.0078^{\star * *} X-0.00002^{*} X^{2}$ & 0.76 & 160.00 & 7.65 & $\mathrm{VH}$ \\
\hline $\mathrm{H}+\mathrm{Al}(80 \mathrm{DAF})$ & $\mathrm{cmol}_{\mathrm{c}} \mathrm{dm}^{-3}$ & $\widehat{Y}=1.0986-0.0038^{* \star *} x+0.00002^{\star * *} x^{2}$ & 0.75 & 95.00 & 0.56 & VL \\
\hline $\mathrm{Ca}(30 \mathrm{DAF})$ & \multirow{3}{*}{$\mathrm{cmol}_{\mathrm{c}} \mathrm{dm}^{-3}$} & $\widehat{Y}=Y m=6.99$ & & & 6.99 & VG \\
\hline $\mathrm{Ca}(80 \mathrm{DAF})$ & & $\widehat{Y}=8.3850-0.0067^{\star \star *} X$ & 0.68 & 160.00 & 7.31 & VG \\
\hline $\mathrm{Ca}(160 \mathrm{DAF})$ & & $\widehat{Y}=Y m=7.30$ & & & 7.30 & VG \\
\hline $\mathrm{Mg}(30 \mathrm{DAF})$ & \multirow{3}{*}{$\mathrm{cmol}_{\mathrm{c}} \mathrm{dm}^{-3}$} & $\hat{Y}=Y m=6.16$ & & & 6.16 & VG \\
\hline $\mathrm{Mg}(80 \mathrm{DAF})$ & & $\widehat{\mathrm{Y}}=1.6578+0.0086^{\star \star} \mathrm{X}$ & 0.74 & 160.03 & 3.03 & VG \\
\hline $\mathrm{Mg}(160 \mathrm{DAF})$ & & $\widehat{Y}=2.5157-0.0156^{\star * *} X+0.00005^{0} x^{2}$ & 0.77 & 160.00 & 1.24 & G \\
\hline$P(30$ DAF $)$ & \multirow{3}{*}{$\mathrm{mg} \mathrm{dm}^{-3}$} & $\widehat{Y}=0.8035+0.0131^{\star \star \star} X$ & 0.81 & 160.00 & 2.90 & VL \\
\hline$P(80 \mathrm{DAF})$ & & $\widehat{Y}=Y m=5.23$ & & & 5.23 & G \\
\hline$P(160$ DAF $)$ & & $\widehat{Y}=Y m=4.22$ & & & 4.22 & G \\
\hline $\mathrm{K}(30 \mathrm{DAF})$ & \multirow{3}{*}{$\mathrm{mg} \mathrm{dm} \mathrm{m}^{-3}$} & $\widehat{Y}=Y m=153.93$ & & & 153.93 & VG \\
\hline $\mathrm{K}(80 \mathrm{DAF})$ & & $\widehat{Y}=15.632+0.1922^{* \star *} X$ & 0.87 & 160.00 & 46.38 & M \\
\hline $\mathrm{K}(160 \mathrm{DAF})$ & & $\widehat{Y}=Y m=148.00$ & & & 148.00 & VG \\
\hline OM (30 DAF) & \multirow{3}{*}{ dag $\mathrm{kg}^{-1}$} & $\widehat{\mathrm{Y}}=\mathrm{Ym}=3.65$ & & & 3.65 & M \\
\hline OM (80 DAF) & & $\hat{Y}=Y m=3.21$ & & & 3.21 & M \\
\hline OM (160 DAF) & & $\widehat{Y}=3.1391+0.0192^{\star \star \star} X-0.00006^{\star \star \star} X^{2}$ & 0.82 & 160.00 & 4.67 & G \\
\hline $\mathrm{V}(30 \mathrm{DAF})$ & \multirow{3}{*}{$\%$} & $\widehat{\mathrm{Y}}=\mathrm{Ym}=90.37$ & & & 90.37 & VG \\
\hline$V(80 \mathrm{DAF})$ & & $\widehat{Y}=89.366+0.0583^{\star * *} X-0.0003^{\star \star *} x^{2}$ & 0.76 & 86.59 & 86.59 & VG \\
\hline$V(160 \mathrm{DAF})$ & & $\widehat{\mathrm{Y}}=\mathrm{Ym}=91.47$ & & & 91.47 & VG \\
\hline
\end{tabular}

DAF - Days after top-dressing fertilization; BFB - Bovine biofertilizer dose responsible for the highest or lowest value of the variable; MxMn - Maximum and minimum value of the variable; CF - Class of fertility of the variable: VL - Very low; M - medium; G - Good; VG - Very good and VH - Very high, according to Ribeiro et al. (1999); ${ }^{0},{ }^{*},{ }^{* *},{ }^{* * *}$ Significant at $0.1,0.05,0.01$ and 0.001 probability levels by t-test, respectively

Table 3. Values of $\mathrm{pH}$, potential acidity $(\mathrm{H}+\mathrm{Al})$ and contents of phosphorus $(\mathrm{P})$, potassium $(\mathrm{K})$, calcium $(\mathrm{Ca})$, magnesium $(\mathrm{Mg})$, organic matter $(\mathrm{OM})$ and base saturation (V) in soil cultivated with $T$. diversifolia and sampled in different periods, in response to different water regimes

\begin{tabular}{|c|c|c|c|}
\hline Variables & DAF & Rainfed & Irrigated \\
\hline $\mathrm{pH}$ in $\mathrm{H}_{2} \mathrm{O}$ & 80 & $7.16 \mathrm{~b}$ & $7.40 \mathrm{a}$ \\
\hline \multirow{3}{*}{$\begin{array}{l}\mathrm{H}+\mathrm{Al} \\
\left(\mathrm{cmol}_{\mathrm{c}} \mathrm{dm}^{-3}\right)\end{array}$} & 30 & $1.09 \mathrm{a}$ & $0.99 \mathrm{~b}$ \\
\hline & 80 & $0.99 a$ & $0.91 \mathrm{~b}$ \\
\hline & 160 & $0.93 a$ & $0.81 \mathrm{~b}$ \\
\hline \multirow{3}{*}{$\begin{array}{l}P \\
\left(\mathrm{mg} \mathrm{dm}^{-3}\right)\end{array}$} & 30 & $1.92 \mathrm{a}$ & $2.35 \mathrm{a}$ \\
\hline & 80 & $5.03 \mathrm{a}$ & $5.44 \mathrm{a}$ \\
\hline & 160 & $4.46 \mathrm{a}$ & $4.16 \mathrm{a}$ \\
\hline \multirow{3}{*}{$\begin{array}{l}\mathrm{K} \\
\left(\mathrm{mg} \mathrm{dm}{ }^{-3}\right)\end{array}$} & 30 & $170.73 \mathrm{a}$ & $137.13 b$ \\
\hline & 80 & $39.00 \mathrm{a}$ & $23.67 \mathrm{~b}$ \\
\hline & 160 & $177.57 \mathrm{a}$ & $116.77 b$ \\
\hline \multirow{3}{*}{$\begin{array}{l}\mathrm{Ca} \\
\left(\mathrm{cmol} \mathrm{Clm}_{\mathrm{C}}^{-3}\right)\end{array}$} & 30 & $7.03 \mathrm{a}$ & $6.95 \mathrm{a}$ \\
\hline & 80 & $7.73 \mathrm{a}$ & $7.90 \mathrm{a}$ \\
\hline & 160 & $7.13 b$ & $7.49 \mathrm{a}$ \\
\hline \multirow{3}{*}{$\begin{array}{l}\mathrm{Mg} \\
\left(\mathrm{cmol}_{\mathrm{c}} \mathrm{dm}^{-3}\right)\end{array}$} & 30 & $1.91 \mathrm{a}$ & $2.35 \mathrm{a}$ \\
\hline & 80 & $2.31 \mathrm{a}$ & $2.16 \mathrm{a}$ \\
\hline & 160 & $1.94 \mathrm{a}$ & $1.47 \mathrm{~b}$ \\
\hline \multirow{3}{*}{$\begin{array}{l}\text { OM } \\
\left(\text { dag kg }^{-1}\right)\end{array}$} & 30 & $3.55 \mathrm{a}$ & $3.75 \mathrm{a}$ \\
\hline & 80 & $3.17 \mathrm{a}$ & $3.25 \mathrm{a}$ \\
\hline & 160 & $3.70 \mathrm{a}$ & $3.73 \mathrm{a}$ \\
\hline \multirow{3}{*}{$\begin{array}{l}V \\
(\%)\end{array}$} & 30 & $89.60 \mathrm{~b}$ & $91.13 \mathrm{a}$ \\
\hline & 80 & $91.07 \mathrm{a}$ & $91.60 \mathrm{a}$ \\
\hline & 160 & $91.02 \mathrm{~b}$ & $91.95 \mathrm{a}$ \\
\hline
\end{tabular}

Means followed by the same letter in the row do not differ significantly $(p>0.05)$ by F test; DAF - Days after top-dressing fertilization

The increase in biofertilizer doses promoted linear increment in the contents of $\mathrm{P}$ and $\mathrm{K}$ of the soil at 30 and 80 DAF, respectively. Compared with the non-fertilized soil, the application of $160 \mathrm{~m}^{3} \mathrm{ha}^{-1}$ of biofertilizer promoted increments of 361 and $297 \%$ in the contents of $\mathrm{P}$ and $\mathrm{K}$ of the soil (Table 2).

The increase in the $\mathrm{P}$ content of the soil at $30 \mathrm{DAF}$ is due to the presence of the nutrient in the biofertilizer and to the reduction of soil $\mathrm{pH}$. The reduction of $\mathrm{pH}$ in alkaline soils increases the content of $\mathrm{H}^{+}$in the soil solution, favoring the solubilization of complexes of calcium phosphate, commonly predominant in soils with $\mathrm{pH}$ above 7 (Chagas Júnior et al., 2010), as observed in the present study, at 30 DAF (Figure 2A).

The increase in $\mathrm{K}$ content in the soil at $80 \mathrm{DAF}$ can be attributed to the mineralization of the $\mathrm{K}$ present in the biofertilizer and to the possible reduction in its leaching due to the increment in soil $\mathrm{pH}$ (Table 2), because of the increase in the negative charges of the soil (Melo et al., 2013).

The application of $160 \mathrm{~m}^{3} \mathrm{ha}^{-1}$ of bovine biofertilizer reduced the content of exchangeable $\mathrm{Ca}^{2+}$ in the soil by 1.07 $\mathrm{cmol}_{\mathrm{c}} \mathrm{dm}^{-3}$ at $80 \mathrm{DAF}$, in comparison to the non-fertilized plots (Table 2), which can be attributed to the increase in the interaction between organic compounds and $\mathrm{Ca}$, reducing the capacity of extraction of exchangeable $\mathrm{Ca}$ from the soil and its availability to the plants (Pavinato \& Rosolem, 2008).

The increment in biofertilizer doses promoted increment in the values of $\mathrm{V}$ and $\mathrm{OM}$ at 80 and $160 \mathrm{DAF}$, respectively. Compared with the control, the application of $160 \mathrm{~m}^{3} \mathrm{ha}^{-1}$ of biofertilizer increased OM content by $1.54 \mathrm{dag} \mathrm{kg}^{-1}$ at $160 \mathrm{DAF}$ and the application of $97 \mathrm{~m}^{3} \mathrm{ha}^{-1}$ of biofertilizer promoted the highest $\mathrm{V}$, at $80 \mathrm{DAF}$ (Table 2). Increases in the values of $\mathrm{OM}$ and $\mathrm{V}$ of the soil with the addition of organic fertilizers are reported in the literature (Strojaki et al., 2013). The increment of OM promotes improvements of soil chemical and physical attributes, resulting in greater availability of nutrients, permeability and water movement in the soil (Krob et al., 2011; Sampaio et al., 2012), besides providing organic acids that are important for the solubility of the minerals and increment in the recycling and mobility of nutrients (Pavinato \& Rosolem, 2008).

The $\mathrm{P}$ content in the soil was not influenced by the presence or absence of irrigation; in contrast, the $\mathrm{K}$ content was higher in the non-irrigated soil in all samplings and the $\mathrm{Mg}$ content was also higher in non-irrigated soils at 160 DAF (Table 3), which can be attributed to the leaching of $\mathrm{K}$ and $\mathrm{Mg}$ in the soil profile in the irrigated system, which may reduce their availability in the surface. In addition, the higher $\mathrm{pH}$ in the irrigated soil can 
reduce the exchangeable $\mathrm{K}$ and $\mathrm{Mg}$, due to the increase in the formation of ionic complexes (Melo et al., 2013).

Irrigation led to increment in Ca content only at $160 \mathrm{DAF}$, differing in $0.36 \mathrm{cmol} \mathrm{dm}^{-3}$ from the non-irrigated treatments (Table 3); this fact can be justified by the relatively high concentration of $\mathrm{Ca}$ in the irrigation water $\left(65.22 \mathrm{mg} \mathrm{L}^{-1}\right)$. Zhang et al. (2015) also observed increment in the concentrations of soluble Ca with the increase in the amount of $\mathrm{Ca}$ added to the nutrient solution with high content of bicarbonate.

The OM content in the soil did not show difference due to the variation in water regime. On the other hand, irrigation promoted increase in $\mathrm{V}$ at 30 and $160 \mathrm{DAF}$, in comparison to the non-irrigated treatments, probably because the irrigated soil showed lower potential acidity $(\mathrm{H}+\mathrm{Al})$ (Table 3$)$.

Irrigation contributed to the increment in the accumulation of $\mathrm{N}, \mathrm{P}, \mathrm{K}, \mathrm{Ca}, \mathrm{Mg}, \mathrm{S}, \mathrm{Zn}, \mathrm{Fe}, \mathrm{Mn}, \mathrm{Cu}$ and $\mathrm{B}$ in the leaves of T. diversifolia at $80 \mathrm{DAF}$, differing from the non-irrigated treatments in 259, 394, 424, 236, 306, 328, 442, 296, 182, 411 and $574 \%$, respectively (Table 4). At 160 DAF, irrigation contributed to the increase in B accumulation in the leaves of T. diversifolia, differing in $175 \%$ in comparison to non-irrigated plants (Table 4). Increments in the amount of nutrients due to irrigation have also been reported by other authors (Alizadeh \& Namaz, 2011; Aquino et al., 2012).

Irrigation promoted increment in the accumulation of all nutrients in the leaves of T. diversifolia at $80 \mathrm{DAF}$ and of $\mathrm{B}$ at 160 DAF (Table 4). This increase is mainly associated with the increment in the yield of irrigated plants, which showed leaf dry matter of $3,163.79$ and $2,632.30 \mathrm{~kg} \mathrm{ha}^{-1}$ at 80 and 160 DAF, respectively, while non-irrigated plants showed values of $1,044.54$ and 2,179.59 $\mathrm{kg} \mathrm{ha}^{-1}$ at 80 and $160 \mathrm{DAF}$, respectively.

The absence of irrigation promoted increment in $\mathrm{Cu}$ accumulation in the leaves of T. diversifolia at 160 DAF differing

Table 4. Accumulation of nutrients in leaves of Tithonia diversifolia at two consecutive cuts, in response to different water regimes

\begin{tabular}{cccc}
\hline Variables & DAF & Rainfed & Irrigated \\
\hline $\mathrm{N}\left(\mathrm{kg} \mathrm{ha}^{-1}\right)$ & 80 & $32.12 \mathrm{~b}$ & $83.13 \mathrm{a}$ \\
\hline $\mathrm{P}\left(\mathrm{kg} \mathrm{ha}^{-1}\right)$ & 160 & $98.17 \mathrm{a}$ & $81.72 \mathrm{a}$ \\
\hline $\mathrm{K}\left(\mathrm{kg} \mathrm{ha}^{-1}\right)$ & 80 & $1.42 \mathrm{~b}$ & $5.60 \mathrm{a}$ \\
& 160 & $6.32 \mathrm{a}$ & $6.07 \mathrm{a}$ \\
$\mathrm{Ca}\left(\mathrm{kg} \mathrm{ha}^{-1}\right)$ & 80 & $21.25 \mathrm{~b}$ & $90.09 \mathrm{a}$ \\
& 160 & $53.31 \mathrm{a}$ & $64.57 \mathrm{a}$ \\
$\mathrm{Mg}\left(\mathrm{kg} \mathrm{ha}^{-1}\right)$ & 80 & $25.88 \mathrm{~b}$ & $61.14 \mathrm{a}$ \\
& 160 & $40.42 \mathrm{a}$ & $50.75 \mathrm{a}$ \\
$\mathrm{S}\left(\mathrm{kg} \mathrm{ha}^{-1}\right)$ & 80 & $3.23 \mathrm{~b}$ & $9.88 \mathrm{a}$ \\
\hline $\mathrm{Zn}\left(\mathrm{g} \mathrm{ha}^{-1}\right)$ & 160 & $8.42 \mathrm{a}$ & $10.38 \mathrm{a}$ \\
& 80 & $1.86 \mathrm{~b}$ & $6.10 \mathrm{a}$ \\
$\mathrm{Fe}\left(\mathrm{g} \mathrm{ha}^{-1}\right)$ & 160 & $5.12 \mathrm{a}$ & $4.46 \mathrm{a}$ \\
\hline $\mathrm{Mn}\left(\mathrm{g} \mathrm{ha}^{-1}\right)$ & 80 & $16.10 \mathrm{~b}$ & $71.23 \mathrm{a}$ \\
$\mathrm{Cu}\left(\mathrm{g} \mathrm{ha}^{-1}\right)$ & 160 & $135.48 \mathrm{a}$ & $151.83 \mathrm{a}$ \\
$\mathrm{B}(\mathrm{g} \mathrm{ha}$ & $-1)$ & $379.22 \mathrm{~b}$ & $1123.27 \mathrm{a}$ \\
\hline
\end{tabular}

Means followed by the same letter in the row do not differ significantly $(p>0.05)$ by $F$ test. DAF - Days after top-dressing fertilization in $186 \%$ from irrigated plants. For the other nutrients studied in the second crop, except for B, there was no significant difference in the accumulation of nutrients in the leaves due to the presence and absence of irrigation (Table 4). This behavior can be associated with the occurrence of rainfalls during the second crop (Figure 1), contributing to the absorption of nutrients and growth and development of non-irrigated plants.

The high content of $\mathrm{HCO}_{3}$ found in the irrigation water used in this experiment $\left(453 \mathrm{mg} \mathrm{L}^{-1}\right)$ may have influenced the solubility of nutrients in the soil, indirectly interfering with the absorption of nutrients by the irrigated plants; in general, it is suggested that the content of $\mathrm{HCO}_{3}$ in the irrigation water is between 0 and $160 \mathrm{mg} \mathrm{L}^{-1}$ (Roosta, 2011).

The decrease in root/shoot ratio due to the increase in the concentrations of $\mathrm{HCO}_{3}$ in the soil has been reported in the literature (Roosta, 2011), which causes reduction in the volume of soil explored by the root system. In addition, it is known that high concentrations of $\mathrm{HCO}_{3}$ in the irrigation water lead to increment in soil $\mathrm{pH}$, promoting indirect effect for balancing the availability of nutrients to the plants until the limit of the ideal $\mathrm{pH}$ range for plant cultivation $\left(\mathrm{pH}\left(\mathrm{H}_{2} \mathrm{O}\right)\right.$ =6.5) (Roosta, 2011).

These results demonstrate high potential of accumulation of nutrients in the leaves of $T$. diversifolia when irrigated; however, fertilization with biofertilizer, despite improving soil chemical properties, did not result in higher accumulation of nutrients.

The conduction of new studies on the nutritional requirement of T. diversifolia in soils with low natural fertility, as well as on its irrigation management, is of great importance to establish recommendations of fertilization and management techniques for this species.

\section{Conclusions}

1. The application of bovine biofertilizer promotes increment in base saturation and contents of organic matter, phosphorus and potassium of the soil.

2. The application of increasing doses of bovine biofertilizer promotes initial reduction in the $\mathrm{pH}$ of the non-irrigated soil, but this behavior is inverted at 80 and 160 days after topdressing fertilization, in both water regimes.

3. Irrigation using water with high concentrations of bicarbonate contributes to the increase in $\mathrm{pH}$, base saturation and calcium content of the soil.

4. Irrigation promotes increment in the accumulation of nitrogen, phosphorus, potassium, calcium, magnesium, sulfur, zinc, iron, manganese and boron in leaves of $T$. diversifolia, associated with the increase in biomass produced in irrigated systems.

\section{Literature Cited}

Alizadeh, O.; Namazi, L. Effect of different irrigation levels on nutrient uptake by mycorrhizal and nonmycorrhizal corn plants as affected by different soil phosphorus content. Advances in Environmental Biology, v.5, p.2317-2321, 2011.

Allen, R. G.; Pereira, L. S.; Raes, D.; Smith, J. Evapotranspiración del cultivo: Guias para la determinación de los requerimientos de agua de los cultivos. Roma: FAO, 2006. 298p. 
Alves, G. S.; Nascimento, J. A. M.; Santos, D.; Alves, S. S. V.; Silva, J. A. Fertilidade do solo cultivado com pimentão sob aplicação de diferentes tipos biofertilizantes. Revista Verde de Agroecologia e Desenvolvimento Sustentável, v.4, p. 33-41, 2009.

Aquino, L. A.; Aquino, R. F. B. A.; Silva, T. C.; Santos, D. F.; Berger, P. G. Aplicação do fósforo e da irrigação na absorção e exportação de nutrientes pelo algodoeiro. Revista Brasileira de Engenharia Agrícola e Ambiental, v.16, p.355-361, 2012. http://dx.doi. org/10.1590/S1415-43662012000400004

Chagas Júnior, A. F.; Oliveira, L. A.; Oliveira, N. A.; Willerding, A. L. Capacidade de solubilização de fosfatos e eficiência simbiótica de rizóbios isolados de solos da Amazônia. Acta Scientiarum Agronomy, v.32, p.359-366, 2010.

Chiconato, D. A.; Simoni, F.; Galbiatti, J. A.; Franco, C. F.; Caramelo, A. D. Resposta da alface à aplicação de biofertilizante sob dois níveis de irrigação. Bioscience Journal, v.29, p.392-399, 2013.

Figueiredo, C. C.; Ramos, M. L. G.; McManus, C. M.; Menezes, A. M. Mineralização de esterco de ovinos e sua influência na produção de alface. Horticultura Brasileira, v.30, p.175-179, 2012. http:// dx.doi.org/10.1590/S0102-05362012000100029

Krob, A. D.; Moraes, S. P.; Selbach, P. A.; Bento, F. M.; Camargo, F. A. O. Propriedades químicas de um Argissolo tratado sucessivamente com composto de lixo urbano. Ciência Rural, v.41, p.433-439, 2011. http://dx.doi.org/10.1590/S0103-84782011005000017

MAPA - Ministério da Agricultura, Pecuária e Abastecimento. Manual de métodos analíticos oficiais para fertilizantes minerais, orgânicos, organominerais e corretivos. Brasília: MAPA, 2007. 141p.

Melo, M. R. S.; Albuquerque Filho, J. A. C.; Silva Júnior, J. G.; Barbosa, R. F.; Silva, E. F. F. Lixiviação iônica em um cultivo de coentro submetido a doses do polímero hidroabsorvente e lâminas de irrigação. Irriga, v.18, p.522-539, 2013. http://dx.doi.org/10.15809/ irriga.2013v18n3p522

Pavinato, O. S.; Rosolem, C. A. Disponibilidade de nutrientes no solo: Decomposição e liberação de compostos orgânicos de resíduos vegetais. Revista Brasileira de Ciência do Solo, v.32, p.911-920, 2008. http://dx.doi.org/10.1590/S0100-06832008000300001

Reis, M. M.; Cruz, L. R.; Costa, G. A.; Barros, R. E.; Santos, L. D. T. Potencial forrageiro da Tithonia diversifolia na alimentação animal. Caderno de Ciências Agrárias, v.7, p.233-245, 2015.

Ribeiro, A. C.; Guimarães, P. T. G.; Alvarez V., V. H. Recomendações para o uso de corretivos e fertilizantes em Minas Gerais: $5^{\mathrm{a}}$ aproximação. 1.ed. Viçosa: Comissão de Fertilidade do Solo do Estado de Minas Gerais, 1999. 359p.
Roosta, H. R. Interaction between water alkalinity and nutrient solution $\mathrm{pH}$ on the vegetative growth, chlorophyll fluorescence and leaf magnesium, iron, manganese, and zinc concentrations in lettuce. Journal of Plant Nutrition, v.34, p.717-731, 2011. http:// dx.doi.org/10.1080/01904167.2011.540687

Ruíz, T. E.; Febles, G. J.; Galindo, J. L.; Savón, L. L.; Chongo, B. B.; Torres, V.; Cino, D. M.; Alonso, J.; Martínez, Y.; Gutiérrez, D.; Crespo, G. J.; Mora, L.; Scull, I.; La O, O.; González, J.; Lok, S.; González, N.; Zamora, A. Tithonia diversifolia, its possibilities in cattle rearing systems. Cuban Journal of Agricultural Science, v.48, p.79-82, 2014.

Sampaio, T. F.; Guerrini, I. A.; Backes, C.; Heliodoro, J. C. A.; Ronchi, H. S.; Tanganelli, K. M.; Carvalho, N. C.; Oliveira, F. C. Lodo de esgoto na recuperação de áreas degradadas: Efeito nas características físicas do solo. Revista Brasileira de Ciência do Solo, v.36, p.1637-1645, 2012. http://dx.doi.org/10.1590/S010006832012000500028

Shahabi, A.; Malakouti, M. J.; Fallahi, E. Effects of bicarbonate content of irrigation water on nutritional disorders of some apple varieties. Journal of Plant Nutrition, v.28, p.1663-1678, 2005. http://dx.doi. org/10.1080/01904160500203630

Silva, A. P. M.; Bono, J. A. M.; Pereira, F. A. R. Aplicação de vinhaça na cultura da cana-de-açúcar: Efeito no solo e na produtividade de colmos. Revista Brasileira de Engenharia Agrícola e Ambiental, v.18, p.38-43, 2014. http://dx.doi.org/10.1590/S141543662014000100006

Silva, F. C. Manual de análises químicas de solos, plantas e fertilizantes. 2.ed. Brasília: Embrapa Informação Tecnológica, 2009. 627p.

Strojaki, T. V.; Silva, V. R.; Somavilla, A.; Da Ros, C. O.; Moraes, M. T. Atributos químicos do solo e produtividade de girassol e milho em função da aplicação de composto de lixo urbano. Pesquisa Agropecuária Tropical, v.43, p.278-285, 2013. http://dx.doi. org/10.1590/S1983-40632013000300002

Villanueva, F. C. A.; Boaretto, A. E.; Firme, L. P.; Muraoka, T.; Nascimento Filho, V. F.; Abreu Júnior, C. H. Mudanças químicas e fitodisponibilidade de zinco estimada por método isotópico, em solo tratado com lodo de esgoto. Química Nova, v.35, p.13481354, 2012. http://dx.doi.org/10.1590/S0100-40422012000700012

Zhang, W.; Xu, F.; Zwiazek, J. J. Responses of jack pine (Pinus banksiana) seedlings to root zone $\mathrm{pH}$ and calcium. Environmental \& Experimental Botany, v.111, p.32-41, 2015. http://dx.doi. org/10.1016/j.envexpbot.2014.11.001 